\title{
KEBERAGAMAAN EKS PENDERITA KUSTA DAN PENGEMBANGAN METODE DAKWAHNYA DI PERKAMPUNGAN REHABILITASI KUSTA DONOROJO JEPARA
}

\author{
Muslimah \\ Universitas Islam Negeri Walisongo Semarang \\ Email: MuslimahDahlan96@gmail.com
}

\begin{abstract}
Patients with leprosy or ex leprosy have a complex problem. They blame the god for his illness, try to suicide and hide from society. From the complex problem of ex leprosy, required the ex leprosy get special dakwah method. da'i must apply exact dakwah method and finally dakwah can be solve a problem and can be increase of religiosity. This research use a qualitative method. The result from this research indicate is ex leprosy have a good religiosity, in belief a god dimension, knowlage dimension and experience dimension. Development of variation da'wa not increase yet all of the religiosity dimension.

Penderita kusta maupun eks penderita kusta mempunyai masalah yang kompleks. Mereka cenderung menyalahkan Tuhan atas keadaannya, mencoba bunuh diri dan bersembunyi secara sosial. Kompleksnya permasalahan yang dihadapi eks kusta menjadikan eks kusta membutuhkan metode khusus dalam meyampaikan pesan dakwah. Da'i harus menentukan metode dakwah yang tepat, sehingga pada akhirnya model dakwah yang diterapkan mampu memecahkan problem yang dihadapi karena penyakitnya dan meningkatkan pemahaman agama. Jenis penelitian ini kualitatif deskriptif. Hasil penelitian ini menunjukkan bahwa eks kusta mempunyai keberagamaan yang baik pada aspek keyakinan, pengetahuan dan konsekuensi. Pengembangan metode dakwah dilakukan melalui variasi belum mampu meningkatkan seluruh aspek keberagamaan.
\end{abstract}

Kata Kunci: Eks Kusta, Keberagamaan, Metode Dakwah

\section{A. Pendahuluan}

Kusta merupakan penyakit yang tidak mudah menular, tetapi kecacatan yang diakibatkan oleh kusta menjadikan ketakutan yang luar biasa sehingga menghadirkan stigma negatif di masyarakat dan menganggap bahwa kusta merupakan penyakit mudah menular dan sangat berbahaya. Stigma negatif tersebut bukan hanya diberikan pada penderita kusta, tetapi juga kepada eks penderita kusta. keberadaan kelompok masyarakat eks kusta memang terpisah dari pergaulan lingkungan masyarakat umum ${ }^{1}$. Empati masyarakat terhadap

1 Heni Purwaningsih, Pola Interaksi Sosial Antara Masyarakat Eks Penderita Kusta Perkampungan Rehabilitasi Kusta Donorejo dengan Masyarakat Dukuh Juwet Kecamatan Banyumanis Donorejo Jepara. Skripsi UIN SUKA Yogyakarta, 2013. hlm:30 
penderita kusta maupun orang yang telah sembuh dari kusta masih minim, sehingga terjadi pemisahan wilayah tempat tinggal dan pergaulan. Eks penderita kusta juga mengalami sulitnya mendapatkan akses lapangan pekerjaan, mengalami masalah sosial, masalah ekonomi, dan masalah keagamaan². Kompleksnya permasalahan kusta yang ada, maka tak jarang penderita kusta maupun eks penderita kusta cenderung menyalahkan Tuhan atas keadaannya, mencoba mengakhiri hidupnya dengan bunuh diri, dan bersembunyi secara sosial. ${ }^{3}$

Eks kusta ataupun seseorang yang mengalami sakit atau mengalami perubahan dalam organ tubuhnya, respon mereka tidak hanya terkait dengan biologis, tetapi akan berpengaruh pada psikologisnya. Respon psikologis ini juga dipengaruhi oleh kondisi sosial dan spiritual seseorang. Karena pada dasarnya manusia terdiri dari dimensi fisik, emosi, intelektual, sosial, spiritual dimana dimensi-dimensi itu harus dipenuhi kebutuhannya. Seringkali permasalahan yang muncul ketika seseorang mengalami suatu kondisi dengan sakit tertentu (misalnya penyakit fisik) mengakibatkan terjadinya masalah psikologi dan spiritual 4. Kesehatan fisik akan berpengaruh pada kesehatan mental atau psikis ${ }^{5}$.

Beragam gambaran keberagamaan orang yang mengalami kusta dan orang yang sembuh dari kusta tergambarkan dari hasil riset Hidayanti bahwa ada penderita kusta yang mencoba untuk bunuh diri sebagai jalan keluar atas penderitaannya ${ }^{6}$. Penderita kusta tersebut tidak menyadari tentang ajaran agamanya dan lupa tentang kehidupan manusia yang harus dipertanggung jawabkan pada Allah SWT. Eks penderita kusta membutuhkan terapi secara holistik terutama perhatian untuk terapi psikososial-psikoreligiunya. Terapi rehabilitasi mental dengan pendekatan agama seringkali melibatkan orang - orang yang ahli dalam bidang agama seperti ulama atau $d a^{\prime} i$.

Mad'u seperti eks penderita kusta tidak selamanya harus menggunakan metode ceramah yang terlalu terbebani dengan muatan - muatan agama, tetapi bagaimana mad'u mendapatkan motivasi, hiburan, dukungan, sugesti empati dan berbagai hal yang menyangkut aspek kejiwaan dan sosial 7. Metode dakwah

2 ChristiNatalie, Kehidupan Sosial mantan Penderita Kusta Di Wisma rehabilitasi Sosial Katolik (WIRESKAT) Dukuh Polaman Desa Sendangharjo Kabupaten Blora. Skripsi Universitas Negeri Semarang. 2013.hlm:60

3 Lusia Kus Anna. 2014, Agama Bantu Hapus Diskriminasi Penderita Kusta, http://lifestyle.Kompas.Com/read/2014/03/22/0750424/Tokoh.Agama.bantu.Hapus.Diskriminasi. Penderita.Kusta diakses 4 November 2017.

4 Yusuf, Ah dkk. Kebutuhan Spiritual Konsep dan Aplikasi Dalam Asuhan Keperawatan. Jakarta: Mitra Wacana Media. 2016. hlm: 45

5 Jalaluddin. Psikologi Agama, Jakarta: PT Raja Grafindo. 1996. hlm: 30

6 Ema Hidayanti, Konseling Islam Bagi Individu Berpenyakit kronis Analisis Pada Pasien kusta RSUD Tugurejo Semarang. Penelitian Individu. IAIN Walisongo Semarang. 2010. hlm: 121

7 Ema Hidayanti, Konseling Islam Bagi Individu Berpenyakit kronis Analisis Pada Pasien kusta RSUD Tugurejo Semarang. Penelitian Individu. IAIN Walisongo Semarang. 2010. hlm: 51 
peranannya sangat penting dalam penyampaian dakwah, metode dakwah yang tidak benar meskipun penyampaian dakwah baik maka pesan dakwah tersebut tetap akan ditolak ${ }^{8}$.

Dari penjelasan di atas membuktikan bahwa ini merupakan suatu fenomena yang menarik untuk dikaji lebih lanjut, mengingat sangat kompleksnya permasalahan eks kusta dan usaha-usaha untuk mengembangangkan metode dakwah yang tepat bagi eks kusta yang merupakan mad'u berkebutuhan khusus. Kajian ini diawali dengan deskripsi singkat kondisi keberagamaan eks penderita kusta di perkampungan rehabilitasi kusta Donorojo Jepara kemudian pengembangan metode dakwah yang diterapkan oleh $d a^{\prime} i$ bagi eks penderita kusta di perkampungan rehabilitasi kusta Donorojo Jepara.

\section{B. Pembahasan}

\section{Keberagamaan Eks Penderita Kusta}

Keberagamaan eks penderita kusta di perkampungan rehabilitasi kusta Donoprojo Jepara dilihat dengan menggunakan teori Glock and Stark yang di dalamnya terdapat lima dimensi keberagamaan yaitu dimensi keyakinan, peribadatan, pengalaman, pengetahuan dan konsekuensi ${ }^{9}$. Secara umum masing-masing kondisi dimensi keberagamaan mereka sebagai berikut:

1. Dimensi keyakinan, eks kusta memiliki keyakinan yang cukup baik dengan Tuhan, mereka sudah mengerti bahwa penyakit kusta bukan merupakan kutukan. Selain itu mereka juga menyakini bahwa segala apa yang telah mereka terima merupakan takdir dari Tuhan.

2. Dimensi ritualistik, eks kusta masih belum rutin dalam menjalankan ibadah shalat wajibnya, selain hal tersebut intensitas membaca Al-qur'an juga sangat jarang. Beberapa alasan yang berbeda muncul dari para responden perihal sebab dia tidak menjalankan shalat. Ditarik dalam garis besar alasan mereka meninggalkan shalat adalah karena alasan perekonomian, selain hal tersebut alasan lain adalah karena sakit yang dideritanya. Kecacatan yang ada pada tubuh mereka membuat mereka harus menjalankan ibadah shalat dengan posisi yang tidak normal, hal tersebut membuat diri mereka tidak yakin dengan ibadah yang dijalaninya.

3. Dimensi Pengalaman, eks kusta mempunyai dimensi pengalaman yang beragam, dimensi pengalaman mereka dapat dikategorikan rendah karena dari sepuluh responden hanya ada satu yang menyatakan bahwa merasakan begitu dekat dengan Allah. Meskipun begitu, beberapa responden tetap hlm: 61

8 Acep Aripudin, Pengembangan Metode Dakwah, Jakarta: PT Raja GrafindoPersada. 2011.

9 Ancok dan Suroso. Psikologi Islami. Yogyakarta: Pustaka Pelajar. 2004. 
menyatakan bahwa mereka juga pernah merasakan kedekatan yang luar biasa dengan Tuhannya.

4. Dimensi pengetahuan, eks kusta rata-rata sudah memiliki pengetahuan yang baik perihal ibadah dan beberapa pengetahuan dasar tentang agama. Pengetahuan dasar agama yang mereka ketahui adalah rukun iman, rukun Islam, masalah bersuci dan kewajiban shalat bagi setiap muslim. Tetapi pengetahuan itu belum diaplikasikan dengan maksimal pada kehidupan sehari-hari mereka. Banyak alasan yang diungkapkan perihal apa yang menyebabkan mereka tidak mengaplikasikan pengetahuan mereka di kehidupan sehari-hari, antara lain adalah karena belum terbiasa.

5. Dimensi Konsekuensi, dimensi konsekuensi eks kusta cukup baik. Eks kusta sangat menjunjung tinggi rasa kebersamaan dan sangat menjaga hubungan silaturahim. Hal tersebut dibuktikan dengan kenyataan bahwa meskipun dari masing-masing mereka bukan orang yang berkecekupupan, tetapi mereka tetap bersedia membantu jika ada warga lain yang kesusahan.

Bermacam-macam keadaan keberagamaan eks kusta di atas tentu mempunyai dasar ataupun faktor tersendiri, menurut hasil penelitian faktor yang paling mempengaruhi adalah faktor perekonomian, karena dengan keadaan fisik yang terbatas dan akses sosial maupun pekerjaan yang sempit mereka cenderung kesusahan untuk memenuhi kebutuhan dasar mereka. Sesuai pendapat Maslow orang tidak akan memikirkan dan tertarik kebutuhan lainnya sebelum kebutuhan dasar ini terpenuhi. Jika ditinjau dari teori Maslow keinginan untuk taat beragama akan sulit berkembang bila orang tersebut masih diliputi perjuangan untuk memenuhi kebutuhan dasarnya. ${ }^{10}$

Keadaan seperti itulah yang harus diperhatikan oleh para da'i, agar meskipun eks kusta dalam keadaan terhimpit tetapi mereka tetap mempertahankan keimanan dan ibadah mereka. Dengan penerapan metode dakwah yang tepat maka keimanan eks kusta yang telah dimiliki tentu dapat dipupuk kembali, sehingga keyakinan eks kusta tidak lagi ada keraguan. Keimanan yang telah tersimpan dalam diri eks kusta diwujudkan dengan keberislaman pula yaitu dengan mengaktualisasikan keimanan dengan amal-amal shaleh sehingga keimanan eks kusta tersebut bukan hanya sebatas dalam hati dan pikiran, tetapi juga dibuktikan dengan perbuatan.

Setelah eks penderita kusta sampai pada tahap ketiga yaitu iman, dibuktikan dengan perbuatan yang mana diekspresikan dengan menjalankan segala perintah Allah dan menjauhi segala larangannya. Selanjutnya dimensi pengalaman eks penderita kusta juga akan ikut serta tumbuh seiring dengan rutinnya mereka menjalankan ibadah dan mendekatkan diri dengan Allah. Pendekatan kepada Tuhannya menjadi sebuah pendorong untuk meningkatkan

10 Ancok dan Suroso. Psikologi Islami. Yogyakarta: Pustaka Pelajar. 2004. 
kepercayaan diri, disamping mampu menerima cobaan dengan hati yang lapang dan sadar menerimanya sebagai sebuah kenyataan.

\section{Pengembangan Metode Dakwah Yang Diterapkan Oleh Da'i Bagi Eks Penderita Kusta}

Kegiatan dakwah yang diterapkan da'i bagi eks penderita kusta dapat diklasifikasikan ke dalam tiga metode dakwah yaitu bi al-hikmah, mauidzah alhasanah dan metode dakwah bi al- hal. Berikut ini digambarkan pengklasifikasian serta penjabaran mengenai metode dakwah yang diterapkan da'i bagi eks penderita penyakit kusta:

a. Penerapan Metode Dakwah Bil Hikmah

Metode dakwah al-hikmah yang dimaksud dalam penelitian ini adalah metode dalam bentuk kata-kata maupun perbuatan da'i yang bernilai Islami. Hikmah merupakan peringatan penting kepada juru dakwah agar tidak hanya menggunakan satu cara dakwah. ${ }^{11}$ Cara demikian agar sesuai dengan kondisi sosial, budaya dan tingkat pendidikan mad'u. Dari hasil penelitian diperoleh bahwa penerapan metode dakwah al-hikmah yang dilakukan da'i di perkampungan rehabilitasi kusta adalah dengan metode memberi contoh akhlak yang baik.Sikap dan perilaku atau akhlak sangat efektif dijadikan cara dakwah hampir pada setiap golongan dan strata mad'u.

Akhlak yang baik sangat dijunjung tinggi dalam Islam. Akhlak adalah cerminan dari totalitas kehidupan kepribadian seseorang. Beberapa akhlak baik yang dipraktikkan di atas diantaranya dengan ucapan salam dan sapaan, salam dan sapaan tersebut merupakan bentuk akhlak terhadap sesama manusia. Tanpa membeda-bedakan antara satu dengan yang lain, baik masyarakat awam, masyarakat terpelajar maupun masyarakat kusta. Sikap demikian merupakan proses saling mengenal dan sosialisasi antar sesama warga sehingga tercipta masyarakat yang rukun, peduli dan saling menghargai antara satu dengan yang lain.

b. Penerapan Metode Dakwah Mauidzah Hasanah

Mauidzah hasanah identik dengan metode yang hanya memberikan wawasan mad'u melalui perkataan atau lisan. Metode mauidzah hasanah yang diberikan pada eks penderita kusta tebentuk dalam kegiatan yang dapat digambarkan sebagai berikut:

1). Kegiatan Tahlil Keliling (Metode Silaturrahim)

11 Acep Aripudin, Pengembanganmetode Dakwh. Jakarta: PT Raja GrafindoPersada. 2011. hlm: 121 
Secara kronologis pada awalnya kegiatan ini dilaksanakan di mushola kampung kusta, tetapi menurut pak Samsuri kesadaran untuk mengikuti kegiatan tersebut masih sedikit, hanya beberapa orang saja yang mau untuk menghadiri yasinan dan tahlilan rutin tersebut. Pada akhirnya tahun 2004 Pak Samsuri yang sebelumnya berunding dengan pak Wagiran dan pak Karim selaku pengurus perkampungan memutuskan kegiatan tersebut dilaksanakan di rumah-rumah warga dengan sistem bergilir. Benar saja bahwa dengan menggunakan cara seperti ini antusias warga cukup tinggi, selama ini hampir semuanya mengikuti acara tahlilan bergilir tersebut.

Metode baru yang merupakan metode silaturrahim yang di dalamnya juga terdapat metode pengajaran sampai saat ini masih berjalan dengan baik. Dengan menggunakan metode ini, da'i dapat menjalin hubungan lebih dekat dengan warga khususnya shohibul bait sehingga da'i mampu untuk lebih membantu sesuai dengan permasalahan yang mereka hadapi.

2). Kegiatan Pengajian rutinan

Hal yang berbeda dari kegiatan ini adalah materi dakwah yang diberikan. Materi dakwah yang disampaikan biasanya berhubungan atau menyesuaikan dengan momen-momen tertentu pada bulan itu. Semisal ketika bulan puasa, maulid nabi dan hari besar Islam lainnya. Respon eks kusta sangat antusias dalam mengikuti kegiatan pengajian ini, tetapi untuk efektif atau tidaknya kegiatan ceramah ini kyai Ali sendiri belum bisa memastikan, karena beliau sendiripun sangat jarang berinteraksi langsung dengan eks kusta ataupun memerhatikan keseharianya. Beliau hanya menyampaikan bahwa beliau yakin saja jika selama ini eks kusta sudah memiliki keyakinan kepada Tuhan dengan baik, begitu pula pengetahuan keagamaan serta kegiatan ritualistik mereka.

c. Penerapan Metode Dakwah Bil-Hal

Dakwah bil hal adalah dakwah dengan perbuatan nyata. Karena itu dalam pelaksanaannya unsur keteladanan merupakan unsur yang paling dominan. Penerapan metode dakwah bil hal ini diberikan oleh da'i kepada eks kusta melalui metode demonstrasi yang dikemas dalam beberapa kegiatan. dakwah bil-hal juga merupakan kategori dari dakwah bil-hikmah. Berikut adalah penjabaran pelaksanaan dakwahnya yang jika disambungkan dengan teoritis merupakan bagian dari metode demonstrasi:

1) Kegiatan Wisata Religi

Alasan diadakannya kegiatan ini karena pada dasarnya eks kusta sendiri hampir tidak pernah merasakan jalan-jalan keluar dari perkampungan. Kegiatan wisata religi ini mendapat respon baik dari eks kusta, mereka antusias dengan ikut serta dalam kegiatan ini. Dakwah melalui wisata religi ini diharapkan dapat memperkaya wawasaan keagamaan dan memperdalam rasa spiritual jamaahnya. Karena bagaimanapun kegiatan dakwah ini ditujukan untuk memenuhi dahaga spiritual akan hikmah-hikmah dari berziarah ke para wali. Para jama'ah 
dapat mengambil i'tibar dari melakukan wisata religi seperti mengingatkan akan kematian dan mengingatkan bahwa segala amal perbuatan di dunia akan dipertanggungjawabkan.

2) Kegiatan Kerjabakti (bersih-bersih kampung)

Kegiatan ini juga dapat dijadikan salah satu metode guna untuk memelihara dan meningkatkan dimensi pengetahuan dan dimensi konsekuensi. Artinya eks kusta dapat menambah pengetahuan dasar yang berkenaan dengan keagamaan mengenai tentang kebersihan lingkungan, mencintai lingkungan dan dimensi konsekuensi yaitu melatih tanggungjawab masing-masing eks kusta, bahwa meskipun lingkungan tersebut bukan merupakan hak milik mereka, meskipun mereka membersihkan bukan hanya di sekitar rumah mereka tetapi mereka tetap mau melaksanakan kegiatan kerjabakti tersebut demi menjaga kebersihan kampung bersama.

Pengembangan metode dakwah yang diterapkan para da'i eks kusta dikemas cantik ke dalam kegiatan-kegiatan keagamaan yang telah berjalan sebelumnya. Dari beberapa kegiatan keagamaan yang diterapkan, sesungguhnya eks kusta sudah sangat antusias dalam mengikuti setiap kegiatan dakwah yang ada di perkampungan eks kusta, tetapi metode tersebut belum terwujud secara maksimal atau secara sempurna, terbukti dari hasil penelitian keberagamaan eks kusta, masih banyak eks kusta yang belum melaksanakan ibadah wajibnya dan mempunyai pengalaman keberagamaan yang belum maksimal.

Pengembangan metode dakwah bagi eks penderita kusta secara garis besar berhaluan pada pengembangan metode al-hikmah yang didukung dengan metode mauidlah hasanah. Indikasinya adalah keterlibatan langsung eks kusta sebagai obyek yang melaksanakan materi dakwah, da'i hanya melakukan rekayasa keadaan sosial dan memberikan pendampingan. Pengembangan metode dakwah yang dilakukan oleh da'i dipandang dari segi output (hasil yang didapat) lebih mengarah pada pembentukan watak, keilmuan dan perilaku eks kusta yang berdasar pada nilai-nilai Islam.

Berikutnya secara teoritis pelaksanaan metode dakwah pada eks kusta menggunakan beberapa pengembangan metode dakwah yaitu metode ceramah, silaturrahim, metode pengajaran dan pendidikan agama dan metode demonstrasi. ${ }^{12}$ Dari beberapa metode dakwah yang telah diterapkan, terlihat dakwah tersebut kurang menyentuh apa yang sebenarnya menjadi kebutuhan mad'u. bahkan jika dianalisis lebih lanjut dari metode ceramah yang diberikanpun belum mendapatkan hasil yang maksimal. Meskipun telah disampaikan materi dakwah yang variataif, yang mengandung motivasi semangat untuk eks kusta, tetapi tetap saja ceramah-ceramah tersebut tidak telihat dalam kehidupan mereka sehari-hari. Dari semua pengembangan metode dakwah yang ada, semuanya

12 Asmuni Syukir, Dasar-Dasar Strategi dakwah Islam. Surabaya. Al-ikhlas. 1989. hlm: 51-60 
dimaksudkan untuk meningkatkan atau mempertebal keberagamaan mereka, tetapi pada kenyataannya mereka hanya mempunyai keyakinan pada Allah, pengetahuan tentang agama islam tetapi tidak diiringi oleh ritualitas dan pengalaman keberagamaan mereka. Kondisi keberagamaan eks kusta tersebut tidak dipungkiri selaras dengan pendapat keberagamaan dapat dipengaruhi oleh faktor-faktor kebutuhan yang tidak terpenuhi terutama faktor pangan, keamanan, cinta kasih, harga diri dan ancaman kematian ${ }^{13}$.

Pengembangan metode dakwah lain yang dibentuk dengan rekayasa sosial ternyata baru menjadikan eks kusta hanya sekedar iman dan Islam, tetapi belum dapat di cerminkan dengan amal shaleh. Atau dapat dikatakan dakwah yang diberikan belum mencapai hakikat dakwah seperti penuturan Muhidin bahwa sesungguhnya hakikat dakwah adalah upaya mengajak dan mengembalikan manusia pada fitrah dan kehanifannya secara integral, serta merupakan upaya penjabaran nilai-nilai Ilahi menjadi amal shaleh dalam kehidupan nyata ${ }^{14}$. Secara singkat dakwah seharusnya diberikan dan difungsikan difungsikan untuk meningkatkan kualitas manusinya baik dari segi sosial, ekonomi dan pendidikan. Para da'i harus lebih jeli untuk memahami apa sesungguhnya kebutuhan atau problem mendasar yang dialami mad'u eks kusta tersebut

Pada dasarnya dakwah yang diberikan kepada eks kusta ini bukan lagi dalam rangka untuk mengajak mereka masuk dalam agama Islam, tetapi lebih untuk memantapkan keimanan yang telah dimiliki, mengarahkan untuk lebih meningkatkan apa-apa yang belum maksimal dalam keberagamaan mereka sehingga pada akhirnya eks kusta mempunyai kehidupan yang bahagia dunia akhirat. Hal serupa sesuai dengan pendapat Aripudin bahwa bagi yang telah memeluk Islam dakwah dimaksudkan sebagai bentuk peringatan, penyegaran dan pencerahan tentang kabar gembira, agar kaum muslimin dan muslimat tetap setia pada fitrah dan kehanifannya secara integral dengan menjalankan perintah agama secara ikhlas, sehingga tetap memiliki kualitas kemanusiaan yang tinggi yaitu bahagia dunia dan akhirat. ${ }^{15}$ Kualitas yang dimaksud adalah beriman, berilmu dan beramal shaleh, yang mencakup dimensi akidah, syariat dan akhlak. ${ }^{16}$

Untuk mencapai ketiga dimensi tujuan dakwah di atas, da'i harus lebih memahami sesungguhnya apa yang menjadi permasalahan dasar mereka. telah diketahui bahwa permasalahan mereka adalah kemiskinan maka menurut hemat penulis da'i hendaknya lebih menggalakkan metode dakwah bil-hal yang ditujukan untuk meningkatkan kualitas dan potensi masyarakat seperti pengembangan

13 Puji Safangatun, Pengaruh Religiusitas Terhadap Kesabaran ( Studi kasus Pada Orang Tua Pasien Anak Di Rumah Sakit Muhammadiyah Darul Istiqomah Kaliwungu Kendal. Skripsi Uin Walisongo Semarang. 2014. hlm:44

14 Wahidin Saputra, Pengantar Ilmu Dakwah. Jakarta: PT Grafindo Persada.2011.

${ }^{15}$ Aripuddin, Pengembangan..., hlm 23

16 Acep Aripudin, Pengembangan metode Dakwah, Jakarta: PT Raja GrafindoPersada. 2011. 
sumberdaya manusia melalui lembaga formal dan informal, pengembangan ekonomi koperasi dan metode pendampingan masyarakat sehingga akan lebih berkembang sesuai dengan tuntutan dan kebutuhan mad'u.

Dari penjelasan di atas dapat diketahui bahwasanya pengaplikasian metode dakwah oleh para da'i bagi eks kusta masih belum relevan. Hal tersebut dipicu karena sesungguhnya da'i belum menyentuh kebutuhan yang paling mendasar dari para eks kusta yaitu masalah ekonomi, padahal sudah dipaparkan oleh mereka sendiri bahwa alasannya sering meninggalkan kewajiban shalatnya karena mereka masih sibuk untuk mengurusi perut mereka. Maka dari itu perlu diberikannya pengembangan metode dakwah yang meliputi pengembangan dari sumber daya manusianya, pengembangan sumberdaya alamnya sehingga eks kusta menjadi masyarakat yang meningkat pada kualitas keIslamannya sekaligus kualitas hidupnya.

\section{Kesimpulan dan Rekomendasi}

Keberagamaan seseorang pada dasarnya dipengaruhi oleh beberapa faktor, baik eksternal maupun internal. Tidak dapat dipungkiri, penerapan metode dakwah juga merupakan hal yang dapat mempengaruhi keberagamaan. Keberagamaan eks kusta dalam penelitian ini menggunakan lima dimensi Glock and Stark yang mana mendapatkan hasil sebagai berikut:

1. Keberagamaan eks kusta menunjukkan mereka mempunyai keberagamaan yang baik pada aspek keyakinan, pengetahuan dan konsekuensi. Hal ini dibuktikan dengan rasa yakin mereka pada Allah dan takdir-Nya, mengetahui kewajiban shalat bagi setiap muslim dalam keadaan apapun, serta sikap tolong-menolong sekalipun dalam keadaan terhimpit. Adapun aspek ritualistik dan pengalaman yang ditunjukkan sepuluh informan, mereka belum menjalankan shalat wajibnya secara rutin dan tidak merasa dekat dengan Allah. Temuan lainnya menunjukkan kurang baiknya dimensi ritualistik dan pengalaman eks kusta ternyata dipengaruhi oleh keadaan ekonomi yang belum mapan dan penerapan metode dakwah yang kurang relevan dengan keadaan eks kusta. Maka dari itu dilakukan upaya pengembangan metode dakwah untuk meningkatkan atau memperbaiki keberagamaan eks kusta.

2. Pengembangan metode dakwah yang dilakukan oleh da'i dari waktu ke waktu menunjukkan variasi dari metode dakwah tahlil dan ceramah dikembangkan menjadi metode silaturrahim, pengajaran Al-qur'an dan demonstasi. Meskipun demikian, metode dakwah yang dilakukan belum mencapai hasil yang maksimal atau belum mampu meningkatkan secara sepenuhnya seluruh aspek keberagamaan. Sebab para da'i belum menyentuh aspek ekonomi yang sejatinya mampu mempengaruhi dan meningkatkan keberagamaan eks kusta.

Berdasarkan hasil penelitian, ada beberapa hal yang dapat penulis sarankan: 
1. Perlu adanya inovasi pengembangan metode dakwah yang sesuai dengan kebutuhan dasar mereka. seperti pengembangan pada aspek ekonomi eks kusta. Mensinergikan semua pihak di lingkungan perkampungan rehabilitasi kusta untuk ikut mendukung dan membantu meningkatkan keberagamaan dan kualitas diri eks penderita kusta.

2. Penentuan metode dakwah eks penderita kusta perlu diperhatikan karakteristik, latar belakang, dan semua kondisi yang ada di eks kusta terutama kebutuhan utama mereka, karena mengingat kembali eks kusta mempunyai masalah yang sangat kompleks baik dari diri mereka sendiri maupun lingkungan masyarakat disekitar eks kusta. 


\section{DAFTAR PUSTAKA}

Amin, Samsul Munir. Ilmu Dakwah. Jakarta: Amzah. 2009.

Ancok dan Suroso. Psikologi Islami. Yogyakarta: Pustaka Pelajar. 2004.

Aripudin, Acep.PengembanganmetodeDakwah.Jakarta: PT Raja GrafindoPersada. 2011.

Aripudin, Acep. Kajian Dakwah Multiperspektif. Bandung: PT Remaja Rosdakarya.2014.

Hidayanti, Ema. Konseling Islam Bagi Individu Berpenyakit kronis Analisis Pada Pasien kusta RSUD Tugurejo Semarang. Penelitian Individu. IAIN Walisongo Semarang. 2010.

Jalaluddin. Psikologi Agama. Jakarta: PT Raja Grafindo. 1996.

Lusia Kus Anna. 2014, Agama Bantu Hapus Diskriminasi Penderita Kusta, http://lifestyle.Kompas.Com/read/2014/03/22/0750424/Tokoh.Agama. bantu.Hapus.Diskriminasi.Penderita.Kusta diakses 4 November 2017.

Natalie, Christi. Kehidupan Sosial mantan Penderita Kusta Di Wisma rehabilitasi Sosial Katolik (WIRESKAT) Dukuh Polaman Desa Sendangharjo Kabupaten Blora. Skripsi Universitas Negeri Semarang. 2013.

Pimay, Awaluddin. Intelektualitas Dakwah Prof. KH. Saifuddin Zuhri. Semarang. RaSAIL. 2010.

Purwaningsih, Heni. Pola Interaksi Sosial Antara Masyarakat Eks Penderita Kusta Perkampungan Rehabilitasi Kusta Donorejo dengan Masyarakat Dukuh Juwet Kecamatan Banyumanis Donorejo Jepara. Skripsi UIN SUKA Yogyakarta, 2013.

Rakhmat, Jalaluddin. Pengantar Psikologi Agama. Bandung: Mizan Pustaka. 2004.

Syukir, Asmuni. Dasar-Dasar Strategi dakwah Islam. Surabaya. Al-ikhlas. 1989. 